J. Clin. Chem. Clin. Biochem.

Vol. 21, 1983, pp. 1-9

\title{
Release of Enzymes from Rat Jejunal Mucosa by Bile Salts
}

\author{
By Bärbel Bossmann ${ }^{1}$ ) and R.J. Haschen \\ Institute of Clinical Biochemistry, Martin Luther University Halle-Wittenberg, Halle, GDR
}

(Received February 25/July 30, 1982)

\begin{abstract}
Summary: The technique of segmental perfusion was applied in vivo to study the release of enzymes from the mucosa cells under the influence of bile salts. Five brush border membrane enzymes, five cytosolic, one mitochondrial and two lysosomal enzymes were measured. Spontaneous release (Ringer solution), due to their superficial localization, was greatest for enteropeptidase and $\alpha$-glucosidase. 3 and $10 \mathrm{mmol} / \mathrm{l}$ sodium taurocholate, and 0.5 and $3.0 \mathrm{mmol} / \mathrm{l}$ chenodeoxycholate were used. Surprisingly, the majority of cytosolic enzymes was released to a greater extent than membrane enzymes. On the other hand, lysosomal or mitochondrial enzymes were low or absent in the perfusion medium, a finding that excludes a serious injury to the mucosa cells. It must be inferred, therefore, that cytosolic enzymes are regularly externalized during the digestive process, the glycocalyx perhaps being a common matrix for pancreatic, membrane-associated and cytosolic enzymes.
\end{abstract}

\section{Freisetzung von Enzymen aus der Jejunumschleimhaut der Ratte durch Gallensalze}

Zusammenfassung: Um die Freisetzung von Enzymen aus den Mucosazellen unter dem Einfluß von Gallensalzen zu untersuchen, wurde die Technik der segmentalen Perfusion angewendet. Es wurden 5 Bürstensaummembranenzyme, 5 cytosolische, 1 mitochondriales und 2 lysosomale Enzyme bestimmt. Die spontane Freisetzung (Ringer-Lösung) war wegen ihrer oberflächlichen Lokalisierung am stärksten bei Enteropeptidase und $\alpha$-Glucosidase. Bei den eingesetzten Gallensalzen handelte es sich um 3 und $10 \mathrm{mmol} / \mathrm{l}$ Natriumtaurocholat und 0,5 und 3,0 mmol/l Chenodesoxycholat. Überraschenderweise wurde die Mehrzahl der cytosolischen Enzyme in höherem Maße freigesetzt als Membranenzyme. Andererseits waren lysosomale oder mitochondriale Enzyme im Perfusionsmedium spärlich oder gar nicht nachzuweisen, ein Befund, der eine schwere Schädigung der Mụcoșazellen ausschließt. Es ist daher anzunehmen, daß während des Verdauungsprozesses regelmäßig cytosolische Enzyme externalisiert werden, wobei die Glycocalyx vielleicht eine gemeinsame Matrix für Pankreas-, Membran- und Cytosolenzyme darstellt.

\section{Introduction}

The release of enzymes by bile salts from the plasma membrane of hepatocytes is well known from clinical and experimental experience. Cholestasis is marked by a significant increase in serum of the membrane enzymes alkaline phosphatase, $\gamma$-glutamyltransferase, alanine aminopeptidase, and others. Experimentally, bile duct ligation, production of intrahepatic. cholestasis by $\alpha$-naphthyl-isothiocyanate, partial hepatectomy and carbon tetrachloride poi-

1) The paper will be part of the thesis of B. Bossmann. soning have been applied $(1,2)$. It has been demonstrated that membrane enzymes in serum are increased only when the bile salt level in liver and serum is elevated. At the same time, the catalytic concentrations of enzymes in the liver may (alkaline phosphatase) or may not ( $\gamma$-glutamyltransferase) be increased. These findings support the concept that the increased serum activities of membrane enzymes in cholestasis are caused by solubilization through bile salts. This has been confirmed by observations with isolated hepatocytes ( 3 ) and with isolated plasma membranes from liver cells (1). In both 
cases considerable amounts of membrane enzymes were released into the supernatant by added bile salts.

Similarly, the release of enzymes from the brush border membrane of the proximal tubules of the kidneys may be increased by as much as 15 -fold in cases of liver disease, particularly in malignant tumours associated with liver metastases (4).

The present work deals with the influence of bile salts on the intestinal brush border membrane. To our knowledge, this problem has only been tackled by Vasseur et al. (5) and Nordström (6), but the examinations were confined to membrane enzymes.

In our investigations, we took advantage of the technique of segmental perfusion; this is characterized by

(1) the possibility of applying exactly the compound to be tested,

(2) of determining precisely the enzymes released, and

(3) of obtaining these results in vivo.

The investigations were not confined to membrane enzymes. Several cytosolic, lysosomal and mitochondrial enzymes were determined as well. The results point to an involvement of the membranes that goes beyond simple release of membrane enzymes through the detergent effect of bile salts.

\section{Materials and Methods}

Female white Wistar rats of an average weight of $200 \mathrm{~g}$ were used, which were on a standard diet (pellets) and water ad libitum. About $1 \mathrm{~h}$ before the operation $0.2-0.3 \mathrm{ml}$ of a $50 \mathrm{~g} / \mathrm{l}$ Brevinar$\operatorname{con}^{\circledR}$ (ethylbutyl thiobarbital-Na) solution was administered to the animals. After laparotomy $20 \mathrm{~cm}$ of the proximal jejunum were exposed and ligated on both ends. Special copnsideration was given to the maintenance of circulation in this segment. Subsequently, in the proximal end of the ligated segment an afferent catheter and in the distal end an efferent catheter was inserted. A peristaltic pump (LKB, Bromma, Șweden) was used for continuous perfusion in a closed system. The duration of the experiments was $2.5 \mathrm{~h}$. In order to maintain the body temperature the animals were placed on an aluminium plate the temperature of which was kept constant by an electric warming-pad at $37^{\circ} \mathrm{C}$. The temperature of the perfusate was regulated by the same device. The volume of the perfusate was $25 \mathrm{ml}$, flow rate $1 \mathrm{ml} / \mathrm{min}$. The following solutions were admiñistered,

(1) in the control experiments Ringer solution containing $9.5 \mathrm{~g} \mathrm{NaCl}, 0.5 \mathrm{~g} \mathrm{KCl}, 0.2 \mathrm{~g} \mathrm{CaCl}_{2}, 0.15 \mathrm{~g} \mathrm{NaHCO}_{3}$ and $1.0 \mathrm{~g}$ glucose per litẹr;

(2) in the bile salt experiments
a) 3 or $10 \mathrm{mmol} / \mathrm{l}$ sodium taurocholate or
b) 0.5 or $3 \mathrm{mmol} / \mathrm{l}$ sodium chenodeoxycholate was added to the Ringer solution.

In some of the experiments with $3 \mathrm{mmol} / \mathrm{l}$ chenonodexycholate the perfusate contained an admixture of mucus increasing with the duration of the experiment. The phenomenon could not be controlled, i.e. it was encountered in some of the animals and missing in others. Therefore we ascribe it to an individual disposition of the animals. In the figures and tables the data of these two groups are represented separately. During the first $1.5 \mathrm{~h}$, samples of $1.7 \mathrm{ml}$ were removed from the perfusate at $15 \mathrm{~min}$ intervals, and afterwards at an interval of $30 \mathrm{~min}$. The volume was replaced by the pertinent solution. The effect of dilution was eliminated by calculation. Protein was determined in the samples by a modified Lowry method (7).

Tab. 1. Summary of enzymes estimated in the perfusate

\begin{tabular}{|c|c|c|c|c|}
\hline Enzyme & EC number & Localization & Author (Ref.) & $\begin{array}{r}\text { Méthod } \\
\text { Substrate, } \mathrm{pH}\end{array}$ \\
\hline Alanine aminopeptidase & 3.4.11. 2 & Membrane & Haschen (8) & $D, L$-alañine $\beta$-naphthylamide, 7.0 \\
\hline Alkaline phosphatase & 3.1. 3.1 & Membrane & DAB 7 (D:-L.) (9) & 4-nitrophenyl phosphate, 10.4 \\
\hline$\gamma$-Glutamyl transferase & 2.3. 2.2 & Membrane & $\dot{\mathrm{DAB}} 7$ (D.-L.) (9) & $L=\gamma$-glutamyl $p$-nitroanilide, 8.2 \\
\hline$\alpha-1,4-G l u c o s i d a s e$ & 3.2. 1.20 & Membrane & $\begin{array}{l}\text { Forner (10), DAB } 7 \\
\text { (D.-L.) (9) }\end{array}$ & maltose, 6.0 \\
\hline Enteropeptidase & 3.4.21. 9 & Membrane & Lebenthal et al. (11) & $\begin{array}{l}\text { trypsinogen, } 6.0 \text {; } \\
\text { benzoyl- } D, L \text {-arginine-p-nitroanilide } 8.2\end{array}$ \\
\hline Leucine aminopeptidase & 3.4 .11 .1 & Cytosol & Haschen et àl. (12) & $L$-leucine hydrazide, 10.4 \\
\hline Glycyl- $L$-leucine dipeptidase & 3.4 .13 .2 & Cytosol & Hanson (13) & glycyl-L-lêucine, 8.2 \\
\hline Diglycinase & 3.4.13.1 & Cytosol & Hanson (13) & glycyl-glycine 8.2 \\
\hline Prolidase & 3.4 .13 .9 & Cytosol & Hanson (13) & glycyl- $L=$ =proline, 8.0 \\
\hline Prolinase & 3.4 .13 .8 & Cytosol & Hanson (13) & $L$-prolylglycine, 8.0 \\
\hline$\beta$-Glucuronidase & 3.2. 1.31 & Lysosomes & Szasz (14) & 4=nitrophenyl $\beta$ - $D$-glucuronide, 4.0 \\
\hline Arylsulphatase A & 3.1. 6.1 & Lysosomes & Baum et al. (15) & 2-hydroxy 5-nitrophenȳl-sulphate, 5.0 \\
\hline Succinate dehydrogenase & 1.3.99.1 & $\begin{array}{l}\text { Mito- } \\
\text { chondria }\end{array}$ & Pennington $_{\mathrm{c}}(16)$ & succinate-Na,$\overline{7} .4$ \\
\hline
\end{tabular}


The enzymes estimated, their localization and the methods used are represented in table 1 . The sources of chemical compounds used were as follows: $D, L$-alanine- $\beta$-naphthylamide- $\mathrm{HCl}$, Serva (Heidelberg); benzoyl- $D, L$-arginine $p$-nitroanilide, Serva (Heidelberg); $L$ - $\gamma$-glutamyl-p-nitroanilide, Lachema (Brno); glycylglycine, Reanal (Budapest); glycyl-L-leucine, Serva (Heidelberg); glycyl-L-proline, Ferak (Berlin); 2-hydroxy-5-nitrophenylsulphate, Sigma (St. Louis); $L$-leucine hydrazide (LAP-Test), VEB Arzneimittelwerk (Dresden); maltose, Merck (Darmstadt); 4-nitrophenyl- $\beta$ - $D$-glucuronide, Merck (Darmstadt); 4-nitrophenylphosphate-Na2, VEB Feinchemie (Sebnitz); L-prolyl-glycine, Ferak (Berlin); sodium taurocholate, Schuchardt (München); sodium chenodeoxycholate, Serva (Heidelberg); succinate- $\mathrm{Na}_{2}$, VEB Laborchemie (Apolda); trypsinogen, Ferak (Berlin).

The direct effect of bile salts on the enzymes was determined by estimating the activity of control samples (obtained after $150 \mathrm{~min}$ of perfusion) before and after addition of bile salts.

In order to be able to express the enzyme activity released as a fraction of the original catalytic activity of the mucosa, homogenates of the latter were examined. The mucosa was scraped off from $20 \mathrm{~cm}$ of proximal jejunum and homogenized with an UltraTurrax homogenizer (Fa. Kunckel, Freiburg/Breisgau) in $25 \mathrm{ml}$ of Ringer solution.

\section{Results}

Total enzyme activity concentrations in jejunal muco: sa

First, the enzyme and protein contents of the jejunal mucosa were estimated (tab. 2). By far the most active enzyme is enteropeptidase. In contrast, little activity is shown by the lysosomal enzymes. The remainder show an intermediate range of between 7 and $60 \mathrm{U}$ per $25 \mathrm{ml}$.

\section{Influence of bile salts on enzyme activity}

Table 3 demonstrates that, with the exception of enteropeptidase, most enzymes are more or less inhibited by bile salts. However, some of them, such as alkaline phosphatase, $\alpha-1,4-$ glucosidase and leucine aminopeptidase, remain practically uninfluenced.
Tab. 2. Enzyme activities in jejunal mucosa homogenate

\begin{tabular}{lc}
\hline Enzyme & Enzyme activity ${ }^{1}$ ) \\
\hline Alanine aminopeptidase & $\left.6.83 \pm 1.48^{2}\right)$ \\
Alkaline phosphatase & $30.48 \pm 9.37$ \\
$\gamma$-Glutamyl transferase & $14.11 \pm 3.42$ \\
Enteropeptidase & $809.87 \pm 162.09$ \\
$\alpha-1,4-G l u c o s i d a s e$ & $57.25 \pm 14.54$ \\
Leucine aminopeptidase & $6.92 \pm 2.39$ \\
Glycyl- $L$-leucine dipeptidase & $52.27 \pm 15.28$ \\
Glycyl-glycine dipeptidase & $23.20 \pm 3.87$ \\
Prolidase & $48.80 \pm 11.14$ \\
Prolinase & $16.00 \pm 1.83$ \\
$\beta$-Glucuronidase & $0.377 \pm 0.080$ \\
Arylsulphatase A & $0.868 \pm 0.270$ \\
Succinate dehydrogęnase & not determined \\
Protein & $188.27 \pm 28.671$ ) \\
\end{tabular}

1) Enzyme activities are expressed as $\mathrm{U}$ per $25 \mathrm{ml}$, protein as $\mathrm{mg}$ per $25 \mathrm{ml}$.

2) Each value represents the average of 10 animals \pm standard deviation

The measured values were corrected for inhibition or activation by bile salts. Thus, the data in the following tables and figures reflect the quantity of enzyme that has been liberated by the bile salt applied.

\section{Rate of enzyme release}

As can be seen from figure 1, after a lag phase of 30$45 \mathrm{~min}$ the enzymes increase in the perfusate in an exponential manner. Ringer solution alone is able to liberate some enzyme material from the enterocytes. As for the influence of the bile salts, in general 3 $\mathrm{mmol} / \mathrm{l}$ taurocholate and $0.5 \mathrm{mmol} / 1$ chenodeoxycholate on one hand and $10 \mathrm{mmol} / \mathrm{l}$ taurocholate and $3 \mathrm{mmol} / \mathrm{l}$ chenodeoxycholate on the other hand are similarly effective. But even the latter is considerably surpassed by those cases in which an admixture of

Tab. 3. Inhibition or activation of enżyme activities by bile salts. The results are given as per cent inhibition or activation (plus signs) (mean \pm standard deviation). The number of experiments is in parentheses. Succinate dehydrogenase was not estimated.

\begin{tabular}{|c|c|c|c|c|c|}
\hline \multirow[t]{2}{*}{ Enzyme } & \multirow{2}{*}{$\begin{array}{l}\text { Sodium taurocholate } \\
3 \mathrm{mmol} / \mathrm{l}\end{array}$} & \multirow{2}{*}{\multicolumn{2}{|c|}{$10 \mathrm{mmol} / \mathrm{l}$}} & \multicolumn{2}{|c|}{ Sodium chenodeoxycholate } \\
\hline & & & & $0.5 \mathrm{mmol} / 1$ & $3 \mathrm{mmol} / 1$ \\
\hline Alanine aminopeptidase & $49 \pm 7(5)$ & $75 \pm$ & $1(5)$ & $12 \pm 4$ (5) & $37 \pm 5 \quad(5)$ \\
\hline Alkaline phosphatase & $6 \pm 6(7)$ & $+5 \pm$ & $5(7)$ & (6) & $4 \pm 2$ (6) \\
\hline y-Glutamyl transferase & $20 \pm 4(5)$ & $38 \pm$ & $13(8)$ & $16 \pm 5(10)$ & $20 \pm 7$ \\
\hline Enteropeptidase & $+150 \pm 66$ & $+100 \mid-200$ & $00(7)$ & $+30 \pm 8(5)$ & $+80 \pm 4$ \\
\hline$\alpha-1,4-G l u c o s i d a s e$ & $0 \quad(4)$ & $+7 \pm$ & $7(4)$ & $0 \quad(4)$ & $+12 \pm 4$ \\
\hline Leucine aminopeptidase & $12 \pm 5$ (9) & $+10 \pm$ & $6(9)$ & $10 \pm 4(8)$ & $+8 \pm 7(10)$ \\
\hline Glycyl-glycine dipeptidase & $5 \pm 5(11)$ & $18 \pm$ & 9 (5) & $8 \pm 6(9)$ & $23 \pm 7$ \\
\hline Glycyl- $L$-leucine dipeptidase & $18 \pm 8(8)$ & $22 \pm$ & $8(10)$ & $18 \pm 10$ & $25 \pm 3$ \\
\hline Prolidase & $10 \pm 8$ (9) & $13 \pm$ & $7(12)$ & (8) & $10 \pm 6$ \\
\hline Prolinase & $10 \pm 5$ (9) & $13 \pm$ & $8(10)$ & $10 \pm 3(5)$ & $10 \pm 6(6)$ \\
\hline$\beta$-Glucuronidase & $8 \pm 2(4)$ & $90 \pm$ & $7(7)$ & (4) & $8 \pm 4$ \\
\hline Arylsulphatase A & $0 \quad(4)$ & 0 & (5) & (3) & (4) \\
\hline
\end{tabular}



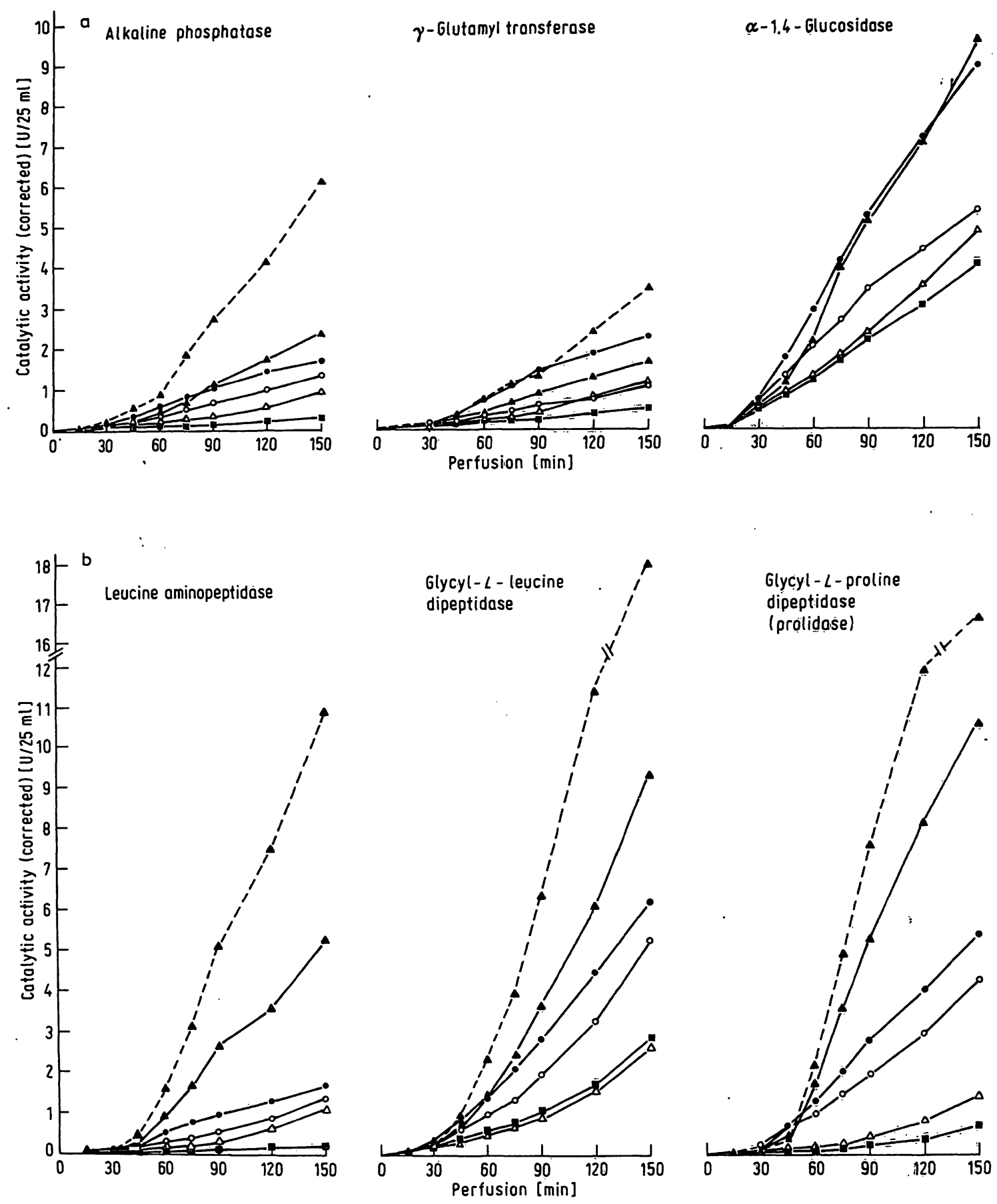

Fig. 1. Course of enzyme release during 150 min perfusion of rat jejunum in vivo with Ringer solution containing different concentrations of taurocholate or chenodeoxycholate. Control Ringer solution. NB: The cytosolic enzymes are released significantly faster than the membrane enzymes represented here (a). Each point corresponds to the mean of $7-26$ experiments. For the sake of clarity the standard deviations are not represented in this figure. The interindividual variation ranged from $10-30(=50) \%$. Taking into account the number of experiments, the standard error of the means, as a percentage, varies.between 2 and $8 .(15 \%)$. The higher values refer to the lower activity concentrations in the first $30-45 \mathrm{~min}$ of the expeniments. For comparison of the bile salt experiments with the controls, Student's t-test was applied. In general, the difference between values after the initial lag phase and controls was highly significant $(p<0.001)$.

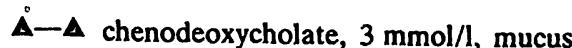

$\Delta-\Delta$ chenodeoxycholate, $3 \mathrm{mmol} / \mathrm{l}$

O-O taurocholate, $10 \mathrm{mmol} / \mathrm{l}$

O-O taurocholate, $3 \mathrm{mmol} / \mathrm{l}$

$\triangle-\triangle$ chenodeoxycholate, $0.5 \mathrm{mmol} / \mathrm{l}$

Q-a control 
mucus appeared in the perfusion medium. In table 4 the final values for all enzymes investigated and for protein are given. The release of protein is comparatively small. Among the enzymes, there are great differences. Only traces of lysosomal and mitochondrial enzymes appear in the perfusate.

\section{Enzyme losses from the mucosa}

Table 5 represents an attempt to compare the total enzyme activity liberated within $150 \mathrm{~min}$ with the initial enzyme content of the mucosa (tab. 2). These results must of course be interpreted with caution since the possibility of continued synthesis of the en- zymes in the mucosa cells has been neglected. Moreover, the activity measurements in the perfusion medium at the end of the experiments due to activation, inhibition or denaturation effects other than by bile salts may be subject to error. A rough estimate however can be made. Neglecting the lysosomal and mitochondrial enzymes, $1-11 \%$ of the enzymes is lost from the mucosa with Ringer solution. By comparison, about the double quantity is liberated by 3 $\mathrm{mmol} / \mathrm{l}$ taurocholate or $0.5 \mathrm{mmol} / \mathrm{l}$ chenodeoxycholate and up to $40 \%$ by the higher concentrations of these bile salts. The excessive values obtained for leucine aminopeptidase might be caused by activation phenomena of unknown origin or by increased synthesis.

Tab. 4. Enzyme activities after $2.5 \mathrm{~h}$ of perfusion with bile salt. The enzyme activities are expressed as $\mathrm{U}$ per $25 \mathrm{ml}$ (mean \pm standard deviation), protein as $\mathrm{mg}$ per $25 \mathrm{ml}$ (mean \pm standard deviation) and have been corrected for direct influence of bile salts. The number of experiments is in parentheses. Arylsulphatase A and succinate dehydrogenase activities were not detectable.

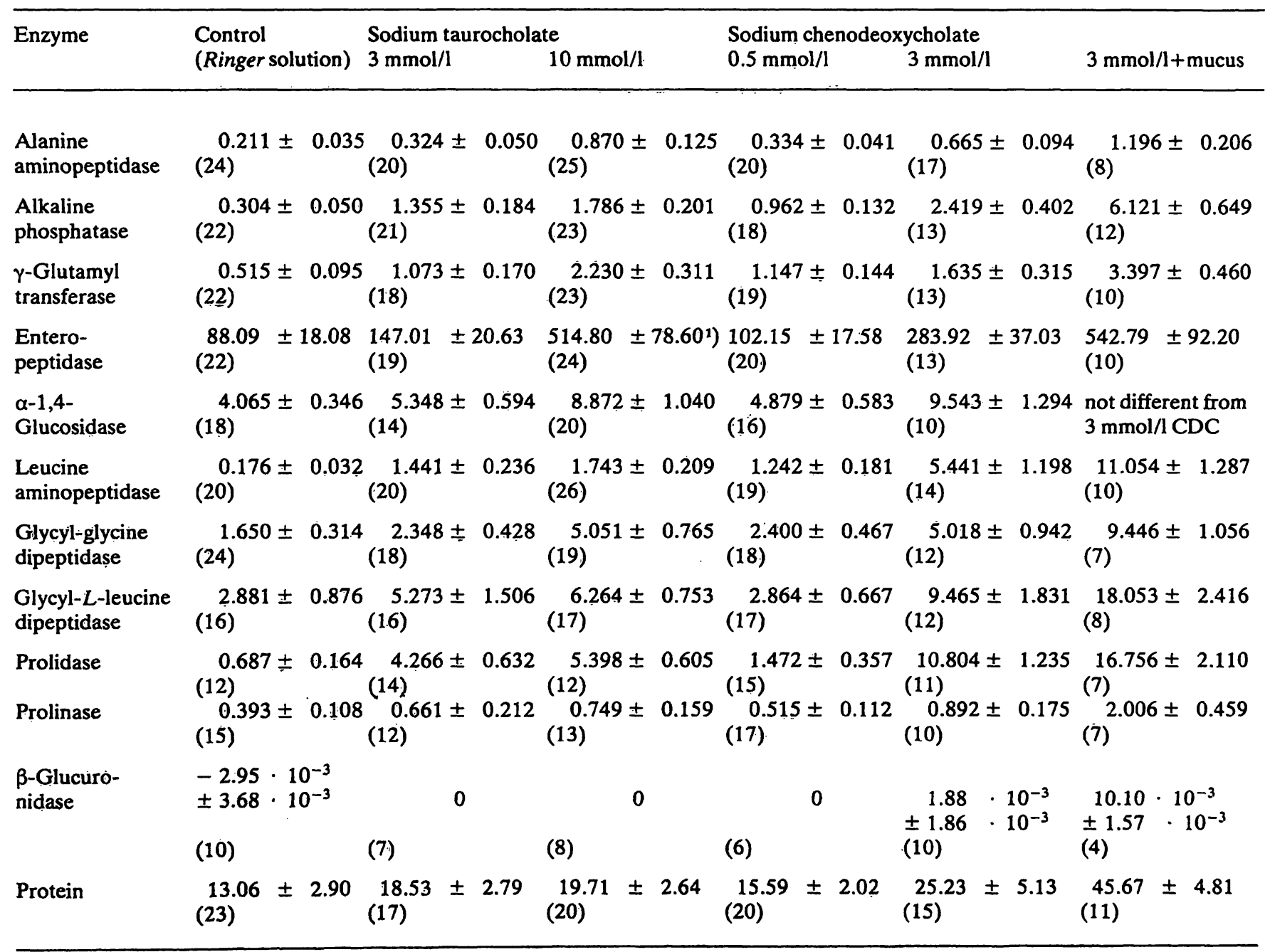

1) The activity of enteropeptidase released by $10 \mathrm{mmol} / \mathrm{l}$ taurocholate has not been corrected since the activation of this enzyme varies from 100-2000 per cent (table 3). 
Tab. 5. Enzymes and protein released from jejunal mucosa after $150 \mathrm{~min}$ of perfusion. Values have been expressed as per cent of the total activity present in the mucosa at zero time.

\begin{tabular}{|c|c|c|c|c|c|c|}
\hline \multirow{2}{*}{\multicolumn{2}{|c|}{$\begin{array}{ll}\text { Control } \\
\text { (Ringer solution })\end{array}$}} & \multicolumn{2}{|c|}{ Sodium taurocholate } & \multicolumn{2}{|c|}{ Sodium chenodeoxycholate } & $3 \mathrm{mmol} / \mathrm{l}+$ mucus \\
\hline & & $3 \mathrm{mmol} / \mathrm{I}$ & & & & \\
\hline $\begin{array}{l}\text { Alanine amino- } \\
\text { peptidase }\end{array}$ & 3.1 & 4.7 & 12.7 & 4.9 & 9.7 & ' 17.5 \\
\hline $\begin{array}{l}\text { Alkaline } \\
\text { phosphatase }\end{array}$ & 1.0 & 4.4 & 5.8 & 3.1 & 7.8 & 19.9 \\
\hline $\begin{array}{l}\gamma \text {-Glutamyl } \\
\text { transferase }\end{array}$ & 3.7 & 7.6 & 15.8 & 8.1 & 11.6 & 24.1 \\
\hline Enteropeptidase & 10.9 & 18.2 & $\left.63.6^{1}\right)$ & 12.6 & 35.1 & 67.0 \\
\hline$\alpha-1,4-$ Glucosidase & 7.1 & 9.3 & 15.5 & 8.5 & 16.7 & 16.7 \\
\hline $\begin{array}{l}\text { Leucine } \\
\text { aminopeptidase }\end{array}$ & 2.5 & 20.8 & 25.2 & 17.9 & 78.6 & 159.7 \\
\hline $\begin{array}{l}\text { Glycyl-glycine } \\
\text { dipeptidase }\end{array}$ & 7.1 & 10.1 & 21.8 & 10.3 & 21.6 & 40.7 \\
\hline $\begin{array}{l}\text { Glycyl-L-leucine } \\
\text { dipeptidase }\end{array}$ & 5.5 & 10.1 & 12.0 & 5.5 & 18.1 & 34.5 \\
\hline Prolidase & 1.4 & 8.7 & 11.1 & 3.0 & 22.1 & 34.3 \\
\hline Prolinase & 2.5 & 4.1 & 4.7 & 3.2 & 5.6 & 12.5 \\
\hline $\begin{array}{l}\text { Succinate } \\
\text { dehydrogenase }\end{array}$ & 0 & 0 & 0 & 0 & 0 & 0 \\
\hline$\beta$-Glucuronidase & 0.8 & 0 & 0 & 0 & 0.5 & 2.7 \\
\hline Arylsulphatase A & 0 & 0 & 0 & 0 & 0 & 0 \\
\hline Protein & 6.9 & 9.8 & 10.5 & 8.3 & 13.4 & 24.3 \\
\hline
\end{tabular}

1) In this case enteropeptidase activity has not been corrected for direct influence of bile salt (see table 4, footnoté).

\section{Discussion}

The bile salts administered should be distinguished according to their different detergent levels. After Greim et al. (17), who were working with liver cells, the dihydroxy bile acid inhibition level ${ }^{2}$ ) corresponds to a concentration of $0.1 \mathrm{mmol} / \mathrm{l}$, the dihydroxy bile acid detergent level to $0.3 \mathrm{mmol} / \mathrm{l}$ and the trihydroxy bile acid detergent level to $3.0 \mathrm{mmol} / \mathrm{l}$. If we apply these data to our experiments, the critical detergent level has been attained or surpassed in all cases. The concentration of $3 \mathrm{mmol} / \mathrm{l}$ chenodeoxycholate would correspond to tenfold the detergent level. Indeed, in some of these experiments, as mentioned above, the perfusate contained an admixture of "mucus" which increased during the experiments and might correspond to micelles consisting of membrane lipids and bile salt. The bile salt concentrations at the detergent level correspond to physiological levels. At this level a slight, reversible functional impairment of the membranes should be envisaged:

2) Inhibition of the endoplasmic cytochrome P-450 oxidase
For the rèst, the liberated enzyme quantities appeär to steadily increase according to the type and concentration of the administered bile salts. In contrast to membrane and cytosol enzyymes the quantities of lysosomal and mitochondrial enzymes range from negligible to zero. Preliminary results of electronmicroscopic investigations indicate that at $3 \mathrm{mmol} / \mathrm{l}$ taurocholate the brush border membranes remain intact except for a removal of the apical glycocalyx. (The complete results of these morphological investigations will be published separately.)

The biochemical findings deserve detailed consideration. In table 6 data have been compiled which are derived from the findings communicated in the Results section. An impression of the nonspecific solvatability of the enzymes can be gained by considering the figures obtained for the controls at 15 and 150 minutes. The spontaneous release varies from $6=$ fold to 40 fold among the membrane enzymès and is greatest for $\alpha-1,4$-glucosidase and enteropeptidase. This corresponds to the quite superficial localization of these enzymes in the plasma membrane (18). As 
Tab. 6. Criteria for the evaluation of the effect of Ringer solution and bile salts. The combined cffect is represented e. g. by the values for $3 \mathrm{mmol} / \mathrm{l}$ chenodeoxycholate after $150 \mathrm{~min}$ of perfusion (see tab. 4). For further details see text.

\begin{tabular}{|c|c|c|c|c|c|c|}
\hline \multirow[t]{2}{*}{ Enzyme } & \multirow[t]{2}{*}{$\begin{array}{l}\text { Controls } \\
150 / 15 \text { min }\end{array}$} & \multicolumn{2}{|l|}{ Taurocholate } & \multicolumn{2}{|c|}{$\begin{array}{l}\text { Bile salt - Control Ratio } \\
\mathrm{mmol} / \mathrm{l} \text { Chenodeoxycholate }\end{array}$} & \multirow[b]{2}{*}{$3+$ mucus } \\
\hline & & 3 & 10 & 0.5 & 3 & \\
\hline $\begin{array}{l}\text { Alanine amino- } \\
\text { peptidase }\end{array}$ & 9.1 & 1.5 & 4.1 & 1.6 & 3.2 & 5.7 \\
\hline $\begin{array}{l}\text { Alkaline } \\
\text { phosphatase }\end{array}$ & 5.9 & 4.1 & 5.9 & 3.2 & 8.0 & 20.1 \\
\hline $\begin{array}{l}\gamma \text {-Glutamyl } \\
\text { transferase }\end{array}$ & 11.2 & 2.1 & 4.3 & 2.2 & 3.2 & 6.6 \\
\hline Enteropeptidase & 33.1 & 1.7 & 5.8 & 1.2 & 3.2 & 6.2 \\
\hline$\alpha-1,4-$ Glucosidase & 38.5 & 1.3 & 2.2 & 1.2 & 2.3 & 2.3 \\
\hline $\begin{array}{l}\text { Leucine } \\
\text { aminopeptidase }\end{array}$ & 12.1 & 8.2 & 9.1 & 7.1 & 30.9 & 62.8 \\
\hline $\begin{array}{l}\text { Glycyl-L-leucine } \\
\text { dipeptidasc }\end{array}$ & 24.9 & 1.8 & 2.2 & 1.0 & 3.3 & 6.3 \\
\hline $\begin{array}{l}\text { Glycyl-glycine } \\
\text { dipeptidase }\end{array}$ & 12.3 & 1.4 & 3.1 & 1.5 & 3.0 & 5.7 \\
\hline Prolidase & 27.5 & 6.2 & 7.9 & 2.1 & 15.7 & 24.4 \\
\hline Prolinase & 17.3 & 1.7 & 1.9 & 1.3 & 2.3 & 5.1 \\
\hline$\beta$-Glucuronidase & 8.7 & - & - & - & 0.6 & 3.4 \\
\hline Arylsulphatase A & - & - & - & - & - & - \\
\hline $\begin{array}{l}\text { Succinate } \\
\text { dehydrogenase }\end{array}$ & - & - & - & - & - & - \\
\hline Protein & 3.7 & 1.4 & 1.5 & 1.2 & 1.9 & 3.5 \\
\hline
\end{tabular}

for the cytosolic enzymes, the increase is more uniform, varying around 20 -fold. The values for bile salts vs. control give an impression of the detergent effect of the former. Among the membrane enzymes, the greatest effect is obtained for alkaline phosphatase and the least one for $\alpha-1,4$-glucosidase. Among the cytosolic enzymes leucine aminopeptidase and prolidase are released most rapidly whereas the smallest effect is exerted on glycyl- $L$-leucine dipeptidase. The combined effects of perfusion per se and of added bile salts are reflected by the total enzyme activities liberated. Except for enteropeptidase, the membrane enzymes are released in similar quantities $(1-10 \mathrm{U} / 25 \mathrm{ml}$ within $2.5 \mathrm{~h})$. As for $\alpha$ 1,4-glucosidase, the great spontaneous release is partially compensated for by the small effect of bile salts. The other membrane enzymes examined are tightly anchored in the lipid bilayer (18). The cytosolic enzymes vary from $1-11 \mathrm{U} / 25 \mathrm{ml}$, i.e. they are released at a similar rate to most of the membrane enzymes. On the other hand, lysosomal and mitochondrial enzymes are practically not liberated from the mucosa cells. This means that in agreement with the preliminary morphological findings mentioned above a serious lesion of these cells can be excluded. What is the biological significance of these findings? Current opinion $(19,20)$ assumes that the digestion of foodstuffs occurs in 3-4 steps,

(1) cleavage of polymeric to oligomeric forms by salivary, gastric and pancreatic enzymes in the intestinal lumen,

(2) splitting of oligomeric to dimeric or monomeric substrates at the surface of the brush border membrane,

(3) resorption of monomers or dimers with a kinetic advantage for the latter, and

(4) terminal cleavage by intracellular enzymes.

Our results lend strong support to the view that the final stage of digestion can take place already in the lumen or at the membrane surface. In this context, the role of the glycocalyx as a possible matrix for pancreatic, cytosolic and membrane enzymes is not sufficiently clarified as yet. It must be inferred from 
our findings that under the influence of bile salts cytosolic enzymes can cross the brush border membrane relatively easily. The mechanism of the membrane passage remains to be elucidated. Elevated bile salt concentrations apparently cause a transitorily increased membrane permeability.

In this context, the unique behaviour of leucine aminopeptidase might become understandable. The enzyme is greatly activated by manganese and/or magnesium ions. The activated enzyme might be formed and retained for a certain time in the glycocalyx. According to earlier investigations $(21,22)$ the substrate used is not hydrolysed by the known membrane aminopeptidases (alanine and aspartate aminopeptidases). Our observation bears some relationship to the findings of Kenney \& Fulcher (23) who investigated renal brush border membranes of the rat. Here, too, a very active "leucine hydrazidase" could be demonstrated. However, there is no doubt that leucine aminopeptidase is a typical soluble cytosolic enzyme which, like other cytosolic di- and tripeptidases, seems to be externalized in small quantities and retained in the glycocalyx for some time.

It is remarkable that the cytosolic enzymes that are released most readily under the influence of bile salts are leucine aminopeptidase and prolidase. Leucine aminopeptidase and the membrane-associated alanine aminopeptidase attack peptides from the $\mathrm{N}$-terminus (for substrate specificity see l.c. $(21,24)$ ) but they are unable to split the gly-pro bond. However, the membrane-associated dipeptidyl peptidase IV (EC 3.4.14.4) is able to remove gly-pro from the amino end of peptides (25) and this dipeptide can be cleaved by prolidase. The "master dipeptidase" of Radhakrishnan (26), glycyl- $L$-leucine hydrolase, has a very broad specifity, but it has no action on the dipeptides gly-gly, gly-his, gly-pro and pro-gly which are hydrolysed by separate cytosolic enzymes.

It might well be that the intracellular hydrolases have still another function, viz. the terminal cleavage of peptides that have been produced by the lysosomal digestion of proteins taken up by autophagy or heterophagy. Thus, the proximal tubular cells of the kidneys regularly take up large quantities of protein from the primary filtrate. It is possible that such a mechanism also takes place in the intestinal cells, particularly if, due to pancreatic insufficiency, proteins and other foodstuffs are supplied in larger quantities.

Apart from the investigations of Bilington et al. (3) and Schlaeger et al. (1) mentioned in the Introduction, studies on the direct effẹct of bile salts on brush border membranes are relatively scarce. However, our findings may be compared with the results obtained by Schmidt et al. (27) in their investigations using isolated perfused rat liver. In one figure (14.6, p. 157) of their paper the ratios of cytosolic and mi:tochondrial enzymes (lactate dehydrogenase/glutamate dehydrogenase and cytosolic/mitochondrial aspartate aminotransferase, respectively) are compared. If $1 \mathrm{mmol} / \mathrm{l}$ sodium deoxycholate is added to the perfusion medium the ratios are very high, but if $1 \mathrm{mmol} / 1 \mathrm{KCN}$ is added they are very low. This means that under the influence of the bile salt cytosolic enzymes are released in relatively large quantities. Another example is given by the data on enzyme activities in serum in cases of acute cholestasis. Immediately after the event, there is a steep rise not only of glutamate dehydrogenase, but also of aspar: tate aminotransferase and the exclusively cytosolic alanine aminotransferase. There follows a rapid de= crease to moderately elevated levels while alkaline phosphatạse and other membrane enzymes do not reach a peak until about one week after the acute occlusion.

Finally, Silk \& Kim (28) observed that on incubation of strips of intestine in vitro there is a very rapid efflux of cytosolic peptidases into the mucoosal medium. This is what we observed at the start of our in= vestigations. Since we thought it might be an artifact due to hypoxia etc., we proceeded to the in vivo experiments presented here. We are thus left with the fact that in vivo and especially under the influence of bile salts cytosolic enzymes may be present at the membrane surface (in the glycocalyx and the lumen) in concentrations not lower than most of the membrane enzymes.

\section{Acknowledgement}

We wish to thank Professor $R$. Kattermann, Mannheim, who kindly made available a copy of the forthcoming paper by Schlaeger, Haux \& Kattermann. The skilful technical assistance of Mrs Brigitte Franz is gratefully acknowledged. 


\section{References}

1. Schlaeger, R., Haux, P. \& Kattermann, R. (submitted for publication).

2. Huseby, N.-E. \& Vik, T. (1978) Clin. Chim. Acta 88, 385-392.

3. Billington, D., Evans, C. E., Godfrey, P. P. \& Coleman, R. (1980) Biochem. J. 188, 321-327.

4. Burchardt, U., Peters, J. E., Neef, L., Thulin, H., Gründig, C. A. \& Haschen, R. J. (1977) Z. Med. Labor.-Diagn. 18, 190-212.

5. Vasseur, M., Ferard, G. \& Pousse, A. (1978) Pflügers Arch. $373,133-138$.

6. Nordström, Ch. (1972) Biochim. Biophys. Acta 289, 367-377.

7. Glässer, D. \& Kleine, R. (1962) Pharmazie 17, 32-36.

8. Haschen, R. J. (1972) in Alaninaminopeptidasen, Biochemie und diagnostische Bedeutung. Wissenschaftl. Beiträge der Martin-Luther-Universität Halle-Wittenberg 1972/4 (R17), p. 95 ff., J. A. Barth, Leipzig.

9. Deutsches Arzneibuch der DDR, 7. Ausgabe (1968), Diagnost. Laboratoriumsmethoden, Band I, Akademie-Verlag, Berlin.

10. Forner, J. (1978) Diplomarbeit, Martin-Luther-Universität Halle-Wittenberg, Bereich Medizin, Halle (Saale).

11. Lebenthal, E., Antonowicz, 1. \& Shwachman, H. (1976) Gastroenterology 70, 508-512.

12. Haschen, R. J., Farr, W. \& Reichelt, D. (1968) Z. Klin. Chem. Klin. Biochem. 6, 11-18.

13. Hanson, H. (1966) in Hoppe-Seyler/Thierfelder, Handbuch der physiologisch- und pathologisch-chemischen Analyse, Band 6, Teil C, S. 40-43, Springer-Verlag, Berlin-Heidelberg-New York.

14. Szasz, G. (1967) Clin. Chim. Acta 15, 275-282.

15. Baum, H., Dodgson, K. S. \& Spencer, B. (1959) Clin. Chim. Acta 4, 453-455.
16. Pennington, R. J. (1961) Biochem. J. 80, 649-654.

17. Greim, H., Schwarz, L., Czygan, P. \& Popper, H. (1975) in Pathogenesis and Mechanisms of Liver Cell Necrosis (Keppler, D. ed.), pp. 199-208, MTP-Press, Lancaster.

18. Moog, F. (1981) Scientific American 245, 116-125.

19. Ugolev, A. M., De Laey, P., Iezuitova, N. N., Rakhimov, K. R., Timofeeva, N. M. \& Stepanova, A. T. (1979) in Development of Mammalian Absorptive Processes, Ciba Foundation Series 70 (new series), p. 221-243, Excerpta Medica, Elsevier, North-Holland, Amsterdam, Oxford, New York.

20. Silk, D. B. A. (1977) in Peptide Transport and Hydrolysis, Ciba Foundation Symp. 50 (new series), p. 15-29, Excerpta Medica, Elsevier, North-Holland, Amsterdam, Oxford, New York.

21. Hütter, H. J., Grävinghoff, J. \& Böhme, I. (1980) Z. Med. Labor.-Diagn. 21, 9-17.

22. Glenner, G. G., McMillan, P. J. \& Folk, J. E. (1962) Nature $194,867$.

23. Kenney, A. J. \& Fulcher, I. S. (1981) in Intracellular Protein Catabolism, Martin-Luther-Universität Halle-Wittenberg, Wiss. Beiträge 1981/29 (R 66), p. 53.

24. Smith, E. L. \& Spackman, D. H. (1955) J. Biol. Chem. 212, 271-299.

25. Wolf, B., Fischer, G. \& Barth, A. (1978) Acta Biol. Med. Germ. 37, 409-420.

26. Radhakrishnan, A. N. (1977) in Peptide Transport and $\cdot H y-$ drolyșis, Ciba Foundation Symp. 50 (new series), p. 37-60, Excerpta Medica, Elsevier, North-Holland, Amsterdam, Oxford, New York.

27. Schmidt, E., Schmidt, F. W., Möhr, J., Otto, P., Vido, I., Wrogemann, K. \& Herfarth, Ch. (1975) in Pathogenesis and Mechanisms of Liver Cell Necrosis (Keppler, D. ed.), pp. 147-162, MTP-Press, Lancaster.

28. Silk, D. B. A. \& Kim, Y. S. (1976) J. Physiol. 258, 489-497.

Prof. Dr. Reinhard Haschen Institut für Klinische Biochemie der Martin-Luther-Universität Leninallee 2 DDR-4020 Halle 
